\title{
Implementasi Akad Ijarah pada Persewaan Perlengkapan Bayi Baby Farra Rental Surabaya
}

\author{
Tiara Dhea Octavianti \\ Institut Agama Islam Negeri (IAIN) Sunan Ampel Surabaya \\ tiaradheaoctavianti@gmail.com
}

Received: August 17, 2020 | Accepted: November 22, 2020 | Published: November 25, 2020

\begin{abstract}
Figh muamalah is a rule or procedure that can be used as a guide for humans to communicate with each other through cooperation using Islamic legal guidelines. One of them is the ljarah method or lease. Meeting the needs of babies is one of the top priorities in the family. One of them is fulfilling the needs of baby equipment which aims to make it easier for parents to care for their children. Besides that, it is also for comfort and helps the development of children. However, the high price and the limited use period along with the development of the baby are the factors inhibiting the fulfillment of these needs. One way to meet these needs is by renting. The baby equipment rental business is one of the most open business opportunities and is needed by the community. One of these business actors is the Baby Farra Rental baby equipment rental. Although the rental system carried out at Baby Farra rental still uses conventional methods. Business owners, employees and consumers of Baby Farra Rental also do not know about what the ljarah Agreement is, but in the implementation of the lease it is in accordance with the principles and conditions of the ijarah including starting from Aqil or the person who leases the lease, sighat contract or consent qabul, ujroh or fee rent and the benefits of the ijarah itself. The existence of a baby equipment rental business is very beneficial financially for the community, especially families who have babies who have economic limitations.
\end{abstract}

Keywords: Contract; ljarah; Rent; Baby Equipment

\begin{abstract}
Abstrak
Fiqh muamalah merupakan aturan atau tata cara yang dapat dijadikan pedoman bagi manusia untuk saling berkomunikasi melalui kerjasama dengan menggunakan pedoman hukum Islam. Salah satunya adalah metode ijarah atau sewa. Pemenuhan kebutuhan bayi merupakan salah satu prioritas utama dalam keluarga. Salah satunya adalah pemenuhan kebutuhan perlengkapan bayi yang bertujuan untuk memudahkan orang tua dalam mengasuh anaknya. Selain itu juga untuk kenyamanan dan membantu tumbuh kembang anak. Namun, mahalnya harga dan masa pakai yang terbatas seiring dengan perkembangan bayi menjadi faktor penghambat dalam pemenuhan kebutuhan tersebut. Salah satu cara untuk memenuhi kebutuhan tersebut adalah dengan cara menyewa. Usaha persewaan perlengkapan bayi merupakan salah satu peluang usaha yang paling terbuka dan sangat dibutuhkan masyarakat. Salah satu pelaku usaha tersebut adalah persewaan perlengkapan bayi Baby Farra Rental. Walaupun sistem persewaan yang dilakukan di persewaan Baby Farra masih menggunakan cara konvensional. Pemilik usaha, karyawan dan konsumen Sewa Baby Farra juga belum mengetahui tentang apa itu Perjanjian ljarah, akan tetapi dalam pelaksanaan sewa sesuai dengan prinsip dan ketentuan ijarah termasuk mulai dari Aqil atau orang yang menyewakan sewa, sighat akad atau ijab qabul, ujroh atau biaya sewa dan manfaat ijarah itu sendiri. Keberadaan usaha persewaan perlengkapan bayi sangat menguntungkan secara finansial bagi masyarakat khususnya keluarga yang mempunyai bayi yang mempunyai keterbatasan ekonomi.
\end{abstract}

Kata kunci: Akad; ljarah; Persewaan; Perlengkapan Bayi 


\section{PENDAHULUAN}

Manusia adalah makluk sosial yang saling membutuhkan satu sama lainnya. Baik untuk bersosialisasi maupun untuk memenuhi kebutuhan hidupnya, seperti kebutuhan primer, sekunder dan tersier. Sebagai makluk ciptaan Allah SWT, manusia tidak hanya diperintahkan untuk beribadah saja akan tetapi juga untuk bermuamalah untuk memenuhi kebutuhan hidupnya tersebut.

Allah SWT telah menciptakan hukum muamalah yang bertujuan untuk mengatur hubungan manusia dengan manusia lain mengenai persoalan jual beli, hutang piutang, sewa-menyewa, upah mengupah, gadai dan lain sebagainya. Fiqih muamalah merupakan aturan atau tata cara yang bisa dijadikan pedoman bagi manusia untuk saling berhubungan dengan lainnya melalui kerjasama dengan menggunakan pedoman hukum islam. Salah satunya yaitu dengan metode ljarah.

ljarah menurut arti bahasa adalah nama upah (As'at, 1979). Menurut pengertian syara', Al ljarah ialah: Suatu jenis akad untuk mengambil manfaat dengan jalan penggantian (Sayyid, 2004). Yang dimaksud dengan sewa-menyewa itu adalah pengambilan manfaat sesuatu benda, jadi dalam hal ini bendanya tidak kurang sama sekali, dengan perkataan lain dengan terjadinya peristiwa sewa-menyewa, yang berpindah hanyalah manfaat dari benda yang disewakan tersebut, dalam hal ini dapat berupa manfaat barang seperti kendaraan, rumah dan manfaat karya seperti pemusik, bahkan dapat juga berupa karya pribadi seperti pekerja (Hairuman, 2004).

Selain jual beli, sewa menyewa menjadi salah satu pilihan seseorang dalam memenuhi kebutuhannya, dikarenakan biaya dari menyewa lebih terjangkau daripada membeli suatu barang.

Bagi keluarga yang baru memiliki keturunan, daftar pemenuhan kebutuhan sehari-hari akan lebih meningkat dari sebelumnya terutama pemenuhan kebutuhan bagi sang buah hati. Tidak hanya berupa kebutuhan utama seperti makanan dan pakaian tetapi juga kebutuhan perlengkapan penunjang bayi seperti tempat tidur bayi, alat gendong bayi, kereta dorong bayi, kursi makan, mainan dan lain-lain. Pemenuhan kebutuhan perlengkapan penunjang bayi ini bertujuan untuk memudahkan orang tua dalam merawat sang buah hati. Disamping itu juga untuk kenyamanan dan membantu tumbuh kembang anak.

Sebagian besar perlengkapan bayi harganya mahal, Hal ini disebabkan karena kebanyakan perlengkapan tersebut berhubungan langsung dengan bayi jadi bahan yang digunakan haruslah aman dan sesuai dengan standar kesehatan bayi agar tidak membahayakan bayi terutama barang- barang yang dipegang dan digigit oleh bayi. Menyewa perlengkapan bayi menjadi salah satu pilihan yang terbaik bagi kami untuk memiliki perlengkapan penunjang bayi tersebut dikarenakan harga yang relatif mahal serta rentan waktu kebutuhan yang tidak lama menjadi alasannya. 


\section{TINJAUAN PUSTAKA}

\section{A. Implementasi}

Implementasi merupakan sesuatu yang bermuara pada aktivitas, aksi, tindakan atau juga aktivitas yang dilakukan secara sistematis serta terikat oleh mekanisme (Usman, 2002).

Oleh karena itu implementasi itu bukan sekedar aktivitas biasa namun suatu kegiatan yang terencana serta untuk mencapai suatu tujuan tertentu. Selain itu implementasi merupakan suatu tindakan atau juga kegiatan atau aktivitas yang dilakukan setelah adanya kebijakan (Tachjan, 2006).

Penerapan implementasi harus sesuai dengan perencanaan yang sudah dibuat supaya hasil yang dicapai sesuai dengan yang diharapkan. Tujuan dari implementasi adalah untuk melaksanakan rencana yang telah atau sudah disusun dengan cermat, baik oleh individu atau juga kelompok sehingga didapatkan hasil yang bisa diuji serta didokumentasikan. Serta untuk mengetahui tingkat keberhasilan suatu kebijakan atau rencana yang telah atau sudah dirancang demi perbaikan atau peningkatan mutu.

Secara umum, implementasi adalah suatu tindakan atau pelaksanaan dari rencana yang telah disusun dengan matang, cermat dan terperinci sehingga sudah ada kepastian dan kejelasan akan rencana tersebut.

\section{B. Akad}

Menurut bahasa arab, akad dapat diartikan sebagai suatu ikatan atau persetujuan. Sedangkan menurut istilahnya akad adalah suatu transaksi atau kesepakatan antara seseorang dengan orang lain untuk pelaksanaan suatu perbuatan yang ditetapkan dengan ijab dan qobul berdasarkan ketentuan syara yang berdampak pada objeknya. Jadi dapat kita simpulkan bahwa akad adalah sebuah perikatan, kesepakatan atau perjanjian, antara pihak-pihak yang menciptakan perjanjian atas suatu objek tertentu dan di shighoh (lafadz) kan dalam ijab-qobul. (Hasan, 2018)

Isi perjanjian atau akad yang telah disepakati hukumnya wajib. Hal ini sesuai dengan firman Allah yang tertulis dalam QS. Al-Maidah ayat 01 (Departemen Agama RI 2012).

Agar pelaksanaan suatu akad dikatakan sah, maka harus memenuhi rukunrukun dari akad. Rukun yang membentuk akad ada empat, yaitu:
a. Para pihak yang membuat akad, yang disebut al-aqidan.
b. Pernyataan kehendak para pihak, yang disebut shigatul-aqd.
c. Objek akad, yang disebut mahallul-aqd.
d. Tujuan akad, yang disebut maudhu' al-aqd. (Ghazali, 2010) 
Dilihat dari pengertiannya, dalam melakukan akad berarti setidaknya harus ada dua pihak yang terlibat. Pihak-pihak ini termasuk dalam rukun akad. Berikut rukun akad.

a. Dua orang atau lebih yang melakukan akad (transaksi) disebut Aqidain.

b. Sighat (Ijab dan Qabul) yaitu pernyataan memberi dan menerima dari kedua belah pihak.

c. Ma'qud 'alaih (sesuatu yang diakadkan). Maksudnya adalah harus ada benda atau hal yang diakadkan. Misalnya jual beli mobil, maka mobil adalah ma'qud alaih.

Disamping rukun ada pula beberapa syarat yang harus terpenuhi dalam sebuah ijab qabul diantaranya adalah :

a. Adanya kejelasan maksud antara kedua belah pihak.

b. Adanya kesesuaian antara ijab dan qabul.

c. Adanya pertemuan antara ijab dan qabul (berurutan dan menyambung).

d. Adanya satu majlis akad dan adanya kesepakatan antara kedua belah pihak, tidak menunjukkan penolakan dan pembatalan dari keduanya. (Sudiarti, 2018)

Sedangkan tujuan dari suatu akad adalah memberi.manfaat kepada kedua belah pihak yang melakukan transaksi. Dengan adanya akad, transaksi.menjadi jelas dan tidak ada yang dirugikan atau saling menguntungkan.

Akad ada beragam jenis teknik yang diungkapkan dalam berakad, yaitu :

a. Teknik tulisan atau kitabah, contohnya dua aqih berjauhan lokasinya maka ijab qabul boleh dengan kitabah atau tulisan.

b. Teknik Isyarat, untuk orang tertentu akad atau ijab qabul tidak bisa dilaksanakan dengan tulisan maupun lisan, contohnya pada orang bisu yang tidak bisa baca maupun tulis.

c. Perbuatan, misalnya seseorang pembeli memberikan sejumlah uang tertentu, lantas penjual menyerahkan barang yang di belinya.

d. Lisan al-Hal, yaitu mengucap dengan lidah atau suara. (Hasan, 2018)

\section{C. ljarah}

Manusia adalah makluk sosial yang tidak dapat hidup sendiri dan saling membutuhkan satu sama lain dalam kehidupannya. Salah satu bentuk interaksi sosial sesama manusia dalam memenuhi kebutuhannya yang sesuai dengan syariat atau mualmalah adalah ljarah atau sewa menyewa.

Ijarah secara etimologi adalah masdar dari kata ajara - yu'jiru, yaitu upah yang diberikan sebagai kompensasi sebuah pekerjaan. (Mustofa, 2019)

Ada beberapa definisi ljarah menurut beberapa ulama fiqh, diantaranya adalah:

a. Menurut pendapat ulama hanafiyah, akad atas suatu kemanfaatan dengan Pengganti. 
b. Menurut pendapat ulama Syafiiyah, akad suatu manfaat yang diketahui kebolehannya dengan serah terima dengan ganti yang diketahui manfaat kebolehannya.

c. Menurut pendapat ulama Malikiyah, akad menjadikan milik suatu pemanfaatan yang mubah dalam waktu tertentu dengan pengganti. (Sudiarti, 2018)

Maka dapat kita simpulkan bahwa, ljarah atau sewa- menyewa adalah penggunaan suatu barang atau jasa yang memberikan manfaat dan yang dipergunakan tidak berkurang dari keadaan semula serta ada batasan waktunya.

Ada perbedaan mendasar antara sewa menyewa dengan jual beli. Dalam akad jual beli hak kepemilikan suatu barang berpindah tangan. Sementara dalam akad sewa menyewa, hak kepemilikan suatu barang tidak berpindah tetapi hanya kegunaan atau manfaat suatu benda yang dialihkan kepada si penyewa. Sedangkan upah ialah salah satu hak pekerja yang diterima sebagai imbalan sesuai dengan kesepakatan.

Dengan demikian sewa menyewa mengandung beberapa unsur, diantaranya adalah:

a. Adanya pihak penyewa dan yang menyewa.

b. Adanya akad antara kedua belah pihak.

c. Adanya objek sewa yang dapat dipergunakan manfaatnya.

d. Adanya imbalan / harga terhadap pemanfaatan objek sewa tersebut.

e. Manfaat objek sewa diketahui secara jelas.

f. Dilaksanakan dalam periode tertentu. (Hasan, 2018)

Dasar-dasar hukum ljarah diantaranya adalah:

a. Al-Quran

Dalam Al-Quran kita dapat menemukan landasan syara' dari ljarah dalam surat At-Talaq ayat 6 (Hasan, 2018)

b. Hadits

Dari hadits, Rasulullah SAW menyuruh membayar upah terhadap orang yang telah dipekerjakan dan sangat menganjurkan agar pembayaran upah itu hendaknya disegerakan setelah pekerjaan itu selesai dikerjakan. (Sudiarti, 2018)

c. Ijma'

Selain ayat dan hadits diatas, ljarah diperbolehkan berdasarkan kesepakatan para ulama atau ljma' karena bermanfaat bagi manusia sebagai salah satu cara dalam kehidupan bermasyarakat untuk memenuhi keterbatasan dan kekurangan. 
Adapun rukun dan syarat dalam melaksanakan ijarah diantaranya:

a. Aqid (orang yang berakad)

Orang yang berakad harus baligh, berakal dan tidak terpaksaatau didasari kerelaan dari kedua belah pihak yang melakukan akad tersebut. Mu'jir adalah sebutan untuk orang yang memberikan upah atau yang menyewakan, sedangkan Musta'jir adalah orang yang menerima upah untuk melakukan sesuatu dan yang menyewakan sesuatu.

b. Shigat akad

Yang dimaksud dengan Sighat akad adalah kalimat ijab qabul. Ialah ungkapan, pernyataan dan penjelasan yang keluar dari salah seorang yang berakad sebagai gambaran kehendak dalam mengadakan akad ijarah. Syarat ijab qabul dalam ljarah harus menyebutkan masa atau waktu yang ditentukan dalam melakukan sewa.

c. Ujroh

Ujroh yaitu diberikan kepada mista'jir atas jasa yang telah diberikan atau diambil manfaatnya oleh mu'jir. ujroh biasa kita sebut dengan upah. (Hendi, 2011)

d. Manfaat

Baik itu manfaat dari suatu objek yang disewa atau jasa dan tenaga dari orang yang bekerja. Adapun syarat dari manfaat tersebut adalah bermanfaat bagi mu'jir, tidak rusak atau cacat, sebelum berakad pemilik harus menjelaskan secara transparan tentang kondisi dan kualitas. Dan yang paling penting manfaat dari objek tidak bertentangan dengan hukum Islam. (Hasan, 2018) ljarah dapat kita bagi menjadi dua macam yaitu:

a. ljarah sewa barang

Sewa barang pada dasarnya adalah jual beli manfaat barang yang disewakan.

b. Ijarah sewa jasa atau tenaga

Jual beli atas jasa atau tenaga yang disewakan tersebut (Mustofa, 2019). Keduanya macam ljarah tersebut boleh dilakukan asalkan memenuhi rukun dan syarat dari ljarah.

ljarah dikatakan telah berakhir apabila akad dari ljarah atau ijab qabul telah terpenuhi, baik itu berupa batasan waktu yang ditentukan telah berakhir maupun pekerjaan telah diselesaikan sesuai kesepakatan di awal. Namun akad ljarah bisa menjadi batal apabila terjadi suatu udzur.

Ulama Hanafiyah menjelaskan adatiga udzur yang dapat merusak akad ljarah, yaitu:

a. Udzur yang terjadi pada pihak penyewa, seperti penyewa pailit atau bangkrut sehingga tidak mampu membayar biayasewa atau upah jasa atau pekerjaan. Apabila si penyewa tidak mampu melanjutkan akad sewa kecuali dengan 
sesuatu yang dapat membahayakan, maka ia berhak untuk menghentikan akad ljarah.

b. Udzur yang terjadi pada pihak yang memberi sewa, misalnya adanya jatuh tempo utang yang tidak dapat terbayar kecuali dengan menjual barang yang ia sewakan, maka akad menjadi fasakh. Contoh lain, apabila barang yang disewakan adalah barang yang baru dibeli ternyata ada cacat yang membuatnya tidak berfungsi maksimal, maka ia berhak mengurungkan atau menghentikan akad ljarah.

c. Udzur yang terjadi pada barang yang disewakan, seperti orang yang menyewa kamar mandi, ternyata di dalamnya airnya habis habis karena sebab tertentu. Dalam kondisi seperti ini maka akad ljarah menjadi rusak dan tidak dapat dilanjutkan (Hasan, 2018).

Apabila terdapat udzur namun akad tetap dilanjutkan, maka akad tidak mengikat kedua belah pihak. Apabila barang yang disewakan rusak atau hilang maka dilihat dahulu bagaimana kejadiannya. Apabila rusak atau hilang bukan karena kelalaian penyewa maka menjadi tanggung jawab pemilik barang yang disewakan. Namun penyewa mempunyai kewajiban untuk menjaga dan merawat barang yang disewa.

\section{Perlengkapan bayi}

Ada banyak sekali perlengkapan yang harus disiapkan ketika memiliki seorang bayi, diantaranya adalah:

a. Pakaian bayi

Perlengkapan yang paling penting adalah pakaian bay yang memiliki bahan yang lembut dan tidak kaku agar nyaman untuk dipakai. Pakaian berupa baju lengan panjang, celana panjang, baju lengan pendek. Celana pendek dan pakaian hangat. Siapkan juga perlengkapan lain seperti topi bayi, sarung tangan, kaos kaki, bedong, gurita bayi dan popok.

b. Peralatan mandi

Untuk menjaga kebersihan perlengkapan mandi mulai dari sabun, sampo, bedak dan compact powder. Selain itu siapkan juga peralatan seperti handuk lembut, gunting kuku, body lotion, baby oil, minyak telon, topi keramas dan bak mandi atau bathub.

c. Peralatan makan.

Perlengkapan makan yang harus disiapkan adalah botol susu, sikat botol, container susu, steam sterilizer, bottle warmer, termos botol, sendok dan piring

d. Perlengkapan tidur

Agar si kecil tertidur dengan nyenyak, sediakan tempat yang nyaman. Gunakan baby box, bantal, guling, selimut yang halus, perlak, alas bayi yang mudah menyerap keringat dan kelambu. 


\section{e. Perlengkapan P3K}

Berupa thermometer, kain kassa, sikat lidah untuk bayi, alcohol 70\%, betadin, kapas steril, peniti dan sedotan ingus.

f. Perlengkapan jalan-jalan

Peralatan yang dipersiapkan adalah gendongan bayi, baby holder, bootle keepe, tas perlengkapan, paying dan stroller bayi. (Anonim, 2020)

Disamping perlengkapan tersebut juga ada mainan bayi yang berfungsi untuk meningkatkan perkembangan aktivitas motorik bayi. Sehingga bayi lebih banyak bergerak dan belajar.

Harga beberapa perlengkapan bayi tidaklah murah karena kebanyakan perlengkapan tersebut berhubungan langsung dengan bayi jadi bahan yang digunakan haruslah aman dan sesuai dengan standar kesehatan bayi agar tidak membahayakan bayi terutama barang- barang yang dipegang dan digigit oleh bayi. Peralatan bayi juga membutuhkan perawatan dan ruang untuk penyimpanan. Disamping itu kita juga harus pikirkan tentang umur atau lama pemakaian perlengkapan bayi tersebut. Karena dengan bertambahnya umur anak maka perlengkapan pun berubah.

\section{E. Perubahan perilaku konsumen dari membeli menjadi menyewa}

Perilaku konsumen melibatkan pemikiran dan perasaan yang mereka alami serta tindakan yang mereka lakukan dalam proses konsumsi. Hal itu juga mencakup segala hal pada lingkungan yang mempengaruhi pemikiran, perasaan, dan tindakan tersebut. Perilaku konsumen yang bersifat dinamis dan melibatkan interaksi dan penukaran sangat penting untuk dikenali (Peter, 2013).

Konsumen akan meyakini informasi yang diterimanya dan memilih merek tertentu untuk dibeli, hal itu berkaitan dengan sikap yang dikembangkan. Kenyakinan-kenyakinan dan pilihan konsumen (preference) atas suatu merek adalah merupakan sikap konsumen. sikap positif terhadap merek tertentu akan memungkinkan konsumen melakukan pembelian terhadap merek itu, sebaliknya sikap negatif akan menghalangi konsumen dalam melakukan pembelian atau menyewa. (Sutisna, 2002)

Faktor-faktor yang mempengaruhi sikap konsumen antara lain:

a. Status Konsumsi

Merupakan pemahaman sifat-sifat kepribadian seperti, tingkat stimulasi optimum, mencari sensasi, mencari hal-hal baru, sangat mempengaruhi perilaku konsumsi dan pemahaman mereka memungkinkan pemasar untuk mengembangkan strategi persuasif yang efektif. Merupakan status sosial yaitu, dengan membatasi setiap kelas sosial dengan banyaknya status yang dipunyai para anggota dibandingkan dengan yang dipunyai para anggota kelas sosial lainnya. Status sering dianggap sebagai penggolongan relatif para anggota setiap 
kelas sosial dari segi faktor-faktor status tertentu. Ketika mempertimbangkan perilaku konsumen dan riset pasar, status paling sering ditentukan dari sudut satu variabel demografis atau lebih cocok seperti, penghasilan keluarga, status pekerjaan, dan pencapaian pendidikan

b. Kesadaran Nilai

Merupakan kesadaran nilai produk yang dirasakan telah digambarkan sebagai trade-off antara manfaat (atau kualitas) produk yang dirasakan dan pengorbanan yang dirasakan baik yang berkaitan dengan keuangan maupun bukan yang diperlukan untuk memperolehnya. Sejumlah riset mendukung pandangan bahwa para konsumen mengandalkan harga sebagai indikator kualitas produk. Beberapa riset telah menunjukkan bahwa konsumen menghubungkan kualitas yang berbeda pada produk identik yang mempunyai etiket harga yang berbeda. Nilai mencerminkan sejumlah manfaat, baik yang berwujud maupun yang tidak berwujud, dan biaya yang dipersepsikan oleh pelanggan. Nilai adalah kombinasi kualitas, pelayanan dan harga yang disebutkan nilai pelanggan. Nilai meningkat seiring meningkatnya kualitas dan pelayanan, dan sebaliknya menurun seiring dengan menurunkan harga, walau faktor-faktor lain juga dapat memainkan peran penting dalam persepsi

c. Perbandingan Kualitas-Harga

Merupakan kualitas-harga mengandalkan merek yang lebih terkenal sebagai indikator kualitas, tanpa benar-benar mengandalkan harga itu sendiri secara langsung. Karena harga sering sekali dianggap sebagai indikator kualitas, beberapa iklan produk dengan sengaja menekankan harga yang tinggi untuk menegaskan pernyataan pemasar mengenai kualitas. Para konsumen menggunakan harga sebagai indikator pengganti kualitas jika mereka mempunyai sedikit informasi yang dapat dipegang, atau jika mereka kurang yakin pada kemampuan mereka sendiri untuk melakukan pilihan atas dasar halhal lain konsumen memiliki sedikit kepercayaan dalam kemampuan mereka sendiri untuk membuat pilihan produk atau layanan dengan alasan lain. Ketika konsumen akrab dengan nama merek, atau memiliki pengalaman dengan produk (atau jasa), atau toko dimana itu dibeli, penurunan harga sebagai faktor penentu dalam evaluasi produk dan pembelian.

d. Pengaruh Sosial

Merupakan konsep kelas sosial secara tidak langsung menyatakan hierarki dimana orang-orang dalam kelas yang sama biasanya mempunyai tingkat status yang sama, sedangkan para anggota kelas lain mempunyai status yang lebih tinggi maupun lebih rendah. Kelas sosial menunjukkan adanya kelompokkelompok yang secara umum mempunyai perbedaan dalam hal pendapatan, gaya hidup, dan kecenderungan konsumsi. Kelas sosial bisa ditunjukkan oleh perbedaan pendapatan yang terjadi pada populasi penduduk. Individu 
membandingkan harta benda mereka sendiri dengan yang dimiliki oleh orang lain dalam rangka untuk menentukan status sosial relatif mereka. Ini jelas dalam masyarakat yang matrelialistis, dimana status sering berasrosiasi dengan daya beli konsumen. Dengan demikian, orang dengan daya beli lebih (lebih harta) memiliki status yang lebih dan mereka yang kurang uang memiliki status yang kurang. (Schiffman, 2015)

Terdapat keterkaitan antara sikap konsumen dan minat menyewa, minat menyewa adalah merupakan bagian dari komponen perilaku konsumen dalam sikap mengkonsumsi, kecenderungan responden untuk bertindak sebelum keputusan menyewa benar-benar dilaksanakan. (Thomas, 2003)

Beberapa faktor yang membentuk minat beli dan sewa yaitu:

a. Sikap orang lain, sejauh mana sikap orang lain mengurangi alternatif yang disukai seseorang akan bergantung pada dua hal yaitu, intensitas sifat negatif orang lain terhadap alternatif yang disukai konsumen dan motivasi konsumen untuk menuruti keinginan orang lain.

b. Faktor situasi yang tidak terantisipasi, faktor ini nantinya akan dapat mengubah pendirian konsumen dalam melakukan pembelian dan menyewa. Hal tersebut tergantung dari pemikiran konsumen sendiri, apakah dia percaya diri dalam memutuskan akan membeli atau menyewa suatu barang atau tidak.

c. Minat menyewa merupakan konsumen adalah sebuah perilaku dari konsumen, dimana konsumen mempunyai keinginan dalam menyewa atau memilih produk, berdasarkan pengalaman dalam memilih menggunakan dan mengkonsumsi atau bahkan menginginkan suatu produk. (Kotler, 2005)

Seorang konsumen yang ingin mencari suatu kepuasan tentang suatu produk akan mencari informasi sebanyak-banyaknya tentang produk tersebut. Jika dorongan kebutuhan konsumen kuat dan obyek yang dicari dapat memenuhi kebutuhan, maka konsumen akan membeli produk tersebut. Minat diartikan sebagai suatu sikap yang membuat orang senang akan obyek, situasi dan ide tertentu. Hal ini akan diikuti oleh perasaan senang dan kecenderungan untuk mencari dan mendapatkan obyek yang diinginkan. Dalam memenuhi kebutuhannya seseorang tidak dapat menghasilkan obyek pemenuhannya sendiri. Sebagian obyek itu dihasilkan atau dibuat oleh pihak lain. Proses pemenuhan kebutuhan yang melibatkan pihak lain akan memulai kegiatan jual beli.

Aspek-aspek yang terdapat dalam minat sewa antara lain:

a. Perhatian, adanya perhatian dari konsumen terhadap suatu produk.

b. Ketertarikan, setelah adanya perhatian maka akan timbul rasa tertarik dalam diri konsumen.

c. Keinginan, berlanjut pada perasaan untuk memiliki produk tersebut. 
d. Keyakinan, kemudian timbul keyakinan pada diri individu terhadap produk tersebut sehingga menimbulkan keputusan (proses akhir) untuk memperolehnya dengan tindakkan membeli.

e. Keputusan menyewa

Disamping beberapa aspek tersebut faktor ekonomi sangat besar pengaruhnya. Dengan adanya dorongan untuk memiliki suatu barang yang bernilai tinggi utnuk menaikkan status sosial dalam hal ini kemapuan dipandang oleh orang lain tetapi memiliki keterbatasan ekonomi maka memnyewa menjadi salah satu alternatif pilihan seseorang.

\section{METODE PENELITIAN}

Jenis penelitian yang digunakan dalam penelitian ini adalah assosiatif, dengan pendekatan kuantitatif. Populasi dalam penelitian ini adalah konsumen produk HNIHPAI (studi pada alfatih business center II HPAI di Kota Bengkulu) yang melakukan pembelian pada Maret tahun 2020 sebanyak 1.395 orang. Dalam menentukan ukuran sampel dari populasi yang akan diteliti, menggunakan rumus slovin sebagai berikut:

\section{HASIL DAN PEMBAHASAN}

A. Analisis penerapan akad ijarah di Baby Farra Rental Surabaya.

Setelah melakukan penelitian mulai dari pengambilan data secara observasi langsung dan tidak langsung, wawancara melalui telepon dan dokumentasi yang sesuai dengan protokol kesehatan dikarenakan wabah Covid19 kemudian mereduksi data hasil penelitian maka dapat dapat diketahui bahwa Sistem sewa menyewa pada Baby Farra Rental Surabaya masih menggunakan metode konvensional namun. Berikut perbandingan pelaksanaan sistem sewa di Baby Farra Rental terhadap penerapan akad ijarah adalah sebagi berikut:

Tabel 1. Analisis Implementasi Akad ljarah

\begin{tabular}{|c|c|c|}
\hline $\begin{array}{l}\text { Peristiwa yang } \\
\text { diamati }\end{array}$ & Praktek akad di Baby Farra & Akad ljarah \\
\hline $\begin{array}{l}\text { Orang yang } \\
\text { melakukan akad }\end{array}$ & $\begin{array}{l}\text { a. Pelaksanaan sewa menyewa } \\
\text { dilakukan tanpa ada paksaan } \\
\text { atas dasar kebutuhan dari } \\
\text { pihak penyewa dan niat } \\
\text { usaha dari pemilik rental. } \\
\text { b. Sewa bisa dilakukan dengan } \\
\text { datang langsung ke } \\
\text { showroom, melalui pesan }\end{array}$ & $\begin{array}{l}\text { orang yang berakad } \\
\text { harus baligh, berakal dan } \\
\text { tidak terpaksa atau } \\
\text { didasari kerelaan dari } \\
\text { kedua belah pihak yang } \\
\text { melakukan } \\
\text { tersebut. }\end{array}$ \\
\hline
\end{tabular}




\begin{tabular}{|c|c|c|}
\hline & $\begin{array}{l}\text { Whatsapp, SMS, Telepone } \\
\text { atau melalui website. } \\
\text { c. Memiliki KTP atau biodata } \\
\text { diri } \\
\text { d. Karyawan berhadapan } \\
\text { langsung dengan penyewa } \\
\text { sebagai perwakilan dari } \\
\text { pemilik barang atau pemilik } \\
\text { usaha. } \\
\text { e. Tanpa perlu menghadirkan } \\
\text { saksi }\end{array}$ & \\
\hline ljab Qobul & $\begin{array}{l}\text { a. Penyewa menyerahkan } \\
\text { Fotocopy biodata sebagai } \\
\text { syarat melakukan sewa } \\
\text { b. Mengisi Formulir sewa yang } \\
\text { berisi perjanjian yang } \\
\text { menyebutkan pemilik } \\
\text { menyewakan suatu barang } \\
\text { tertentu kepada penyewa } \\
\text { dengan syarat dan ketentuan } \\
\text { baik itu tentang jenis barang, } \\
\text { keadaan dan lama waktu } \\
\text { sewa dan biaya sewa yang } \\
\text { disetujui oleh penyewa yang } \\
\text { disertai dengan materai. } \\
\text { c. Penyewa dapat mengecek } \\
\text { barang terlebih dahulu } \\
\text { sebelum diterima, apabila } \\
\text { ada ketidaksesuaian boleh } \\
\text { ditukar atau dikembalikan. }\end{array}$ & $\begin{array}{l}\text { Sighat akad adalah } \\
\text { kalimat ijab qabul. Ialah } \\
\text { ungkapan, pernyataan } \\
\text { dan penjelasan yang } \\
\text { keluar dari salah seorang } \\
\text { yang berakad sebagai } \\
\text { gambaran kehendak } \\
\text { dalam mengadakan } \\
\text { akad ijarah. Syarat ijab } \\
\text { qabul dalam ljarah harus } \\
\text { menyebutkan masa atau } \\
\text { waktu yang ditentukan } \\
\text { dalam melakukan sewa. }\end{array}$ \\
\hline Jasa sewa & $\begin{array}{l}\text { a. Besaran sewa telah } \\
\text { ditentukan ditunjukkan pada } \\
\text { Brosur produk yang } \\
\text { disewakan berdasarkan jenis } \\
\text { barang dan lama sewa } \\
\text { b. Sewa dibayarkan sebelum } \\
\text { barang diantar atau dibawa } \\
\text { oleh penyewa. }\end{array}$ & $\begin{array}{l}\text { Jasa sewa dalam akad } \\
\text { ijarah dinamakan ujroh. } \\
\text { Ujroh yaitu diberikan } \\
\text { kepada mista'jir atas jasa } \\
\text { yang telah diberikan atau } \\
\text { diambil manfaatnya }\end{array}$ \\
\hline
\end{tabular}




\begin{tabular}{|c|c|c|}
\hline & $\begin{array}{l}\text { c. Penyewa wajib membayar } \\
\text { uang deposit sebagai jaminan } \\
\text { dan akan dikembalikan } \\
\text { setelah masa sewa berakhir } \\
\text { atau barang sudah } \\
\text { dikembalikan. } \\
\text { d. Penyewa memiliki tanggung } \\
\text { jawab untuk menjaga dan } \\
\text { merawat barang selama } \\
\text { masa sewa. } \\
\text { e. Apabila terjadi kerusakan } \\
\text { selama masa sewa maka } \\
\text { menjadi tanggung jawab } \\
\text { penyewa. }\end{array}$ & \\
\hline Manfaat & $\begin{array}{l}\text { a. Penyewa mendapatkan } \\
\text { manfaat terpenuhi } \\
\text { kebutuhannya. } \\
\text { b. Pemilik keuntungan upah. } \\
\text { c. karyawan mendapatkan gaji } \\
\text { penghasilan. }\end{array}$ & $\begin{array}{l}\text { Baik itu manfaat dari } \\
\text { suatu objek yang disewa } \\
\text { atau jasa dan tenaga dari } \\
\text { orang yang bekerja. } \\
\text { Adapun syarat dari } \\
\text { manfaat tersebut adalah } \\
\text { bermanfaat bagi mu'jir, } \\
\text { tidak rusak atau cacat, } \\
\text { sebelum berakad pemilik } \\
\text { harus menjelaskan } \\
\text { secara transparan } \\
\text { tentang kondisi dan } \\
\text { kualitas }\end{array}$ \\
\hline
\end{tabular}

Dari tabel 1. maka dapat disimpulkan sebagai berkut:

a. Aqid (orang yang berakad)

Pada Baby Farra Rental pelaksanaan sewa menyewa dilakukan tanpa ada paksaan atas dasar kebutuhan dari pihak penyewa dan niat usaha dari pemilik rental. Sudah dapat dipastikan bahwa penyewa dan pemilik usaha telah baligh dan berkeluarga. Dalam sewa, pelanggan atau penyewa juga menyerahkan fotocopy KTP dan Kartu keluarga sebagai info biodata penyewa.

b. Shigat akad (kalimat ljab qabul)

Shigat akad atau kalimat ljab qabul pada usaha Baby Farra Rental tertuang dalam formulir perjanjian sewa yang menyebutkan pemilik menyewakan suatu 
barang tertentu kepada penyewa dengan syarat dan ketentuan baik itu tentang jenis barang, keadaan dan lama waktu sewa dan biaya sewa yang disetujui oleh penyewa. Perjanjian sewa hanya dilakukan penyewa dan pemilik usaha dalam hal ini diwakilkan kepada karyawan tanpa perlu menghadirkan saksi

c. Ujroh (jasa sewa)

Dalam sewa menyewa di Baby Farra Rental juga telah ditentukan besaran sewa atau Ujroh dari tiap jenis barang. Besaran sewa ditentukan oleh pemilik Baby Farra Rental berdasarkan lamanya peminjaman dan hal tersebut tertuang dalam formulir perjanjian sewa.

d. Manfaat

Barang yang disewakan sudah tentu bermanfaat bagi penyewa karena sewa dilakukan atas dasar kebutuhan dari penyewa sedangkan pemilik mendapatkan keuntungan dari biaya sewa sedangkan karyawanmendapatkan penghasilan dari gaji bulanan. Di Baby Farra Rental sebelum barang diberikan ke pelanggan, karyawan memberikan penjelasan tentang kondisi barang dan cara menggunakannya. Serta penyewa dapat melakukan pengecekan kondisi barang secara langsung sebelum disewa sehingga penyewa mengetahui secara pasti kondisi dan keadaan barang yang disewa.

\section{B. Pandangan hukum islam terhadap akad ljarah pada Persewaan Perlengkapan} Bayi di Baby Farra Rental Surabaya.

Dari hasi penelitian ini maka dapat diketahui bahwa pemilik usaha, karyawan dan konsumen Baby Farra Rental tidak mengetahui tentang apa itu Akad ljarah . namun dalam pelaksanaan sewa menyewa telah sesuai dengan rukun dan syarat ijarah diantaranya mulai dari Aqil atau orang yang melakukan sewa menyewa, sighat akad atau ijab qabulnya, ujroh atau biaya sewa serta manfaat dari ijarah sehingga dapat disimpulkan pelaksanaan sistem sewa telah sesuai dengan akad ijarah.

C. Manfaat persewaan perlengkapan bayi Baby Farra Rental bagi masyarakat.

Dari beberapa data yang diambil melalui wawancara dengan pemilik, karyawan dan pelanggan Baby Farra Rental dapat kita ketahui bahwa :

a. Pemilik usaha Baby Farra Rental mendapatkan manfaat secara ekonomi dari menyewakan perlengkapan bayi kepada pelanggan.

b. Karyawan Baby Farra Rental, mendapatkan manfaat secara ekonomi juga dari gaji setra mendapatkan pengalaman selam bekerja.

Pelanggan Baby Farra rental mendapatkan manfaat secara ekonomi juga dalam hal terpenuhinya kebutuhan perlengkapan bayi dengan cara menyewa yang dirasa lebih murah daripada membeli. 


\section{SIMPULAN}

Sistem sewa yang dilakukan pada Baby Farra rental masih menggunakan metode konvensional. Pemilik usaha, karyawan dan konsumen Baby Farra Rental tidak mengetahui tentang apa itu Akad ljarah, namun dalam pelaksanaan sewa menyewa telah sesuai dengan rukun dan syarat ijarah diantaranya mulai dari Aqil atau orang yang melakukan sewa menyewa, sighat akad atau ijab qabulnya, ujroh atau biaya sewa serta manfaat dari ijarah itu sendiri.

Pemilik usaha Baby Farra Rental mendapatkan manfaat secara ekonomi dari menyewakan perlengkapan bayi kepada pelanggan serta karyawan mendapatkan manfaat secara ekonomi juga dari gaji dan mendapatkan pengalaman selama bekerja. Sedangkan bagi masyarakat pada umumnya terutama pelanggan Baby Farra rental mendapatkan manfaat secara ekonomi juga dalam hal terpenuhinya kebutuhan perlengkapan bayi dengan cara menyewa yang dirasa lebih murah daripada membeli.

Disamping itu penulis juga menyimpulkan beberapa saran diantaranya perlu adanya pergantian barang yang sudah lama dan rusak dengan barang baru serta penambahan dalam hal jumlah, macam dan jenis barang yang disewakan, penambahan karyawan baru terutama ahli dalam bidang perawatan dan membantu mengambil dan mengantarkan barang kepada pelanggan dan diharapkan Persewaan perlengkapan bayi Baby Farra Rental Surabaya dapat menerapkan Akad ljarah dalam pelaksanaan sewa menyewa seiring dengan beragamnya kebutuhan masyarakat atas penerapan hukum islam dalam perekonomian.

\section{DAFTAR PUSTAKA}

Anonim, perlengkapan bayi, diakses dari https://satujam.com/perlengkapan-bayi/, 9 april 2020.

As'ad Aliy, Tarjamah Fathul Mu'in 2, Kudus: Menara Kudus. 1979

Departemen Agama Republik Indonesia, Al-Qur"an dan Terjemahnya, Jakarta: CV. Kathoda, 2005.

Departemen Agama RI, Al-Quran dan Terjemahannya, Jakarta: Lautan Lestari, 2012.

Emzir, Metodologi Penelitian Kualitatif Analisis Data, Jakarta: Rajawali Pers, 2011.

Sayyid Sabiq , Fikih Sunah 13, terj. Kamalludin A. Marzuki, Jakarta: Pena Pundi Aksara, 2004.

Ghazali Rahman, Abdul, dkk. Fiqih Muamalat, Jakarta:Kencana Prenada Media Group, 2010.

Hasan Akhmad Farroh, Fiqh Muammalah, Malang: UIN-Maliki Press, 2018. 
Kinnear, Thomas C, dan Taylor, James R.. Riset Pemasaran (Edisi Ketiga). Jakarta : Erlangga. 2003

Kotler, Philip,. Manajemen Pemasaran, Terjemahan Edisi Kesebelas Jilid 1. Jakarta, Indeks Kelompok Gramedia. 2005.

Mustofa Imam, Fiqih Mu'amalah Kontemporer, Depok: Rajawali Pers, 2019.

Pasaribu Hairuman dan Suhrawardi K. Lubis, Hukum Perjanjian Dalam Islam, Jakarta : Sinar Grafika, 2004.

Peter, Paul J. dan Jerry C. Olson. Consumer Behavior: Perilaku Konsumen dan Strategi Pemasaran. Dialihbahasakan oleh Damos Sihombing. Jakarta: Erlangga. 2013.

Schiffman, L. G. \& Wisenblit, J. L. Consumer Behavior Edisi 11 Global Edition England: Pearson Education Limited. 2015.

Sudiarti Sri, Fiqh Muamallah Kontemporer, Medan, FEBI UIN-SU Press, 2018.

Sugiyono, Metode Penelitian Kuantitatif Kualitatif Dan R\&D, Bandung: Alfabeta, 2015.

Suhendi Hendi, Fiqh Muamalah, Jakarta: Rajawali Pers, 2011.

Sutisna. (2002). Perilaku Konsumen \& Komunikasi Pemasaran. Bandung: PT Remaja RosdakaryaTachjan, Implementasi Kebijakan Publik, Bandung: AIPI, 2006.

Usman Nurdin, Konteks implementasi berbasis Kurikulum, Bandung: CV Sinar,2002. 